\title{
CLINICAL PATTERN OF ACUTE GALLSTONE PANCREATITIS IN MANIPUR
}

\author{
Chetan Maibam ${ }^{1}$, Suchitra Chongtham ${ }^{2}$, T. Arun Kumar Singh ${ }^{3}$, Th. Sudhir Chandra Singh ${ }^{4}$, Sapam Opendro Singh ${ }^{5}$, \\ Chinglaiphaba Chongtham 6
}

${ }^{1}$ Assistant Professor, Department of Surgery, Regional Institute of Medical Sciences, Imphal.

${ }^{2}$ Assistant Professor, Department of Biochemistry, Jawaharlal Nehru Institute of Medical Sciences, Porompat.

3 Professor and HOD, Department of Surgery, Jawaharlal Nehru Institute of Medical Sciences, Porompat.

${ }^{4}$ Professor, Department of Surgery, Regional Institute of Medical Sciences, Imphal.

${ }_{5}^{5}$ Associate Professor, Department of Surgery, Regional Institute of Medical Sciences, Imphal.

6Junior Resident, Department of Surgery, Regional Institute of Medical Sciences, Imphal.

\section{ABSTRACT}

Acute pancreatitis occurs only in 4-8\% of patients with gallstone disease and 50\% acute pancreatitis recur within 1-6 months. As in other parts of country, the incidence of gallstone disease has been increasing in our region. This study has been carried out in our hospital to find out the disease pattern.

\section{MATERIALS AND METHODS}

All the patients admitted with acute gallstone pancreatitis during the period were included. Various biochemical parameters and radiological investigations like x-ray, Ultrasonography (USG), Computerized Tomography (CT) of abdomen were done in all patients. The treatment plan was focused on adequate initial resuscitation, supportive care and early detection of complications. Duration of stay in the hospital, complications and followup were recorded.

\section{RESULTS}

Thirty two patients were included in the study; 41-60 years was the most common age group. Male:Female ratio was 1:2.2. Meitei was most commonly affected ethnic group. Epigatric pain and tenderness were the most common clinical features. Most (75\%) of the patient's serum amylase was above three times the upper normal limit. Ultrasonography diagnosed $75 \%$ of cases, whereas computerized tomography diagnosed $100 \%$. Average hospital stay was 8 days. Complications included pleural effusion and pseudocyst.

\section{CONCLUSION}

Genetic basis of occurrence of gallstone pancreatitis among the various ethnic groups of Manipur needs to be addressed. Serum amylase and ultrasonography were useful initial diagnostic modality. The acceptance of index cholecystectomy in our local population is very low and the awareness of treatment modalities has to be increased.

\section{KEYWORDS}

Acute Gallstone Pancreatitis, Serum Amylase, Ethnicity.

HOW TO CITE THIS ARTICLE: Chetan Maibam, Suchitra Chongtham, T. Arun Kumar Singh, Th. Sudhir Chandra Singh, Sapam Opendro Singh, Chinglaiphaba Chongtham. "Clinical Pattern of Acute Gallstone Pancreatitis in Manipur." Journal of Evolution of Medical and Dental Sciences 2015; Vol. 4, Issue 102, December 21; Page: 16713-16716, DOI: 10.14260/jemds/2015/2501

\section{INTRODUCTION}

Acute pancreatitis occurs only in $4-8 \%$ of patients with gallstone disease and $50 \%$ acute pancreatitis recur within 1 6 months whenever patient is not submitted to cholecystectomy and cleansing of common bile duct. ${ }^{1}$ It is reported that differences exist between the sexes in their predisposition toward gallstone pancreatitis. ${ }^{2}$

Gallstones are the leading cause of pancreatitis worldwide accounting for at least one half of the 4.8-24.2 cases of pancreatitis per 100,000 people that occur in Western countries. 3,4

Financial or Other, Competing Interest: None.

Submission 09-12-2015, Peer Review 10-12-2015,

Acceptance 16-12-2015, Published 18-12-2015.

Corresponding Author:

Dr. Chetan Maibam,

Thangmeiband Sinam Leikai,

Watham Leirak,

Imphal West,

Manipur-795004.

E-mail: chetan_cmk@rediffmail.com

DOI:10.14260/jemds/2015/2501
About 80,000 cases occur in the USA per year, 17 per 100,000 new cases. ${ }^{5}$ In Japan, annual incidence lies between 5 to 80 per 100,000 of the population. ${ }^{6}$ In China, gallstones account for approximately $50-70 \%$ of the cases of acute pancreatitis. $^{7}$

Incidence of gallstone disease is increasing worldwide. A positive correlation for acute gallstone pancreatitis incidence with an increase in the incidence of gallstone disease in Sweden between 1985 and 1999 was reported with increase of $7.6 \%$ per year. ${ }^{8}$ In Denmark, increased incidence of acute gallstone pancreatitis in female from 17.1 per 1,00,000 person-year in 1981 to 37.8 per $1,00,000$ person-year in 2000 and in male from 18 per $1,00,000$ person-year in 1981 to 27.1 per $1,00,000$ person-year in 2000 was reported. ${ }^{9}$ As in other parts of country, the incidence of gallstone disease has been increasing in our region. Correspondingly, an increased incidence of gallstonerelated acute pancreatitis is also expected. But, there is no previous study regarding gallstone-related acute pancreatitis in our Institute. This study has been carried out in our hospital to find out the disease pattern. 


\section{AIMS}

1. To study the clinical presentation of acute gallstone pancreatitis.

2. To study the management and outcome of the acute gallstone pancreatitis.

\section{MATERIALS AND METHODS}

This prospective cross-sectional study was done in Department of Surgery, Regional Institute of Medical Sciences (RIMS), Imphal, from 1st September 2010 to 31 ${ }^{\text {st }}$ August 2012. All patients admitted in surgical wards who were diagnosed as having acute gallstone pancreatitis were included in the study. Patients having chronic pancreatitis, pancreatitis associated with malignancy were excluded. This study included all the age groups and both the sex.

Various biochemical parameters and radiological investigations like x-ray, Ultrasonography (USG), Computerized Tomography (CT) scan of abdomen were done in all patients.

The treatment plan was focused on adequate initial resuscitation, supportive care and early detection of complications. All the 32 patients were treated conservatively with intravenous fluids, analgesics, proton pump inhibitors and were offered index/interval cholecystectomy with or without CBD exploration.

Informed consent was taken from the patient. Ethical clearance was obtained from the Institutional Ethics Committee, RIMS, Imphal, prior to conducting the study.

\section{RESULTS}

In the present study out of 80 patients of acute pancreatitis, 32 of them were diagnosed to have acute gallstone pancreatitis and were analysed. The rest of acute pancreatitis cases having other etiologies as mentioned in Table 1 were excluded.

\begin{tabular}{|c|c|c|}
\hline Cause & No. of patients & Percentage (\%) \\
\hline Alcohol & 40 & 50 \\
\hline Gallstone & 32 & 40 \\
\hline Idiopathic & 6 & 7.5 \\
\hline Helminthiasis & 1 & 1.25 \\
\hline Hyperparathyroidism & 1 & 1.25 \\
\hline \multicolumn{2}{|c|}{ Table 1: Showing Incidence of } \\
Acute Gallstone Pancreatitis \\
\hline
\end{tabular}

The highest incidence $(68.75 \%)$ was noted in $41-60$ years of age with a median age of 48 years (Range 25-71 years). We had female predominance of acute gallstone pancreatitis with $68.75 \%$ of cases, whereas $31.25 \%$ of them were malses. Male:Female ration of 1:2.2 was noted.

\begin{tabular}{|c|c|c|}
\hline Ethnicity & Number & Percentage (\%) \\
\hline Meitei & 20 & 62.5 \\
\hline Meitei Pangal (Muslim) & 6 & 18.75 \\
\hline Nepali & 2 & 6.25 \\
\hline Naga & 2 & 6.25 \\
\hline Kuki & 2 & 6.25 \\
\hline \multicolumn{2}{|c|}{ Table 2: Showing Ethnic Distribution } \\
\hline
\end{tabular}

Highest number of acute gallstone pancreatitis was seen in Meitei ethnic groups as shown in the Table 2.

\begin{tabular}{|c|c|c|}
\hline Symptoms & Number & Percentage (\%) \\
\hline Epigastric pain & 32 & 100 \\
\hline Nausea/vomiting & 30 & 87.5 \\
\hline Jaundice & 10 & 31.25 \\
\hline Fever & 10 & 31.25 \\
\hline Abdominal distension & 2 & 6.25 \\
\hline \multicolumn{2}{|c|}{ Table 3: Showing symptomatology } \\
\hline
\end{tabular}

In the present study, all the patients presented with pain epigastrium as shown in the Table 3.

\begin{tabular}{|c|c|c|}
\hline Signs & No. of patients & Percentage \\
\hline Epigastric tenderness & 32 & 100 \\
\hline Bowel sound absent & 12 & 37.5 \\
\hline Hypotension & 6 & 18.75 \\
\hline Ascities & 4 & 12.5 \\
\hline Mass abdomen & 2 & 6.25 \\
\hline Table 4: Showing Signs of Acute Gallstone Pancreatitis \\
\end{tabular}

On examination, all the patients had epigastric tenderness and none of them had mass per abdomen as shown in the Table 4.

\begin{tabular}{|c|c|c|}
\hline Investigation & Elevated & $\begin{array}{c}\text { Percentage } \\
\text { (\%) }\end{array}$ \\
\hline S. Bilirubin (>2mg/dl) & 12 & 37.5 \\
\hline S. AST (>150 IU/L) & 16 & 50 \\
\hline $\begin{array}{c}\text { S. Alkaline phosphatase } \\
(>300 \text { IU/L) }\end{array}$ & 8 & 25 \\
\hline S. Amylase (3x UNL) & 24 & 75 \\
\hline $\begin{array}{c}\text { Random blood sugar } \\
(>150 \mathrm{mg} / \mathrm{dL})\end{array}$ & 12 & 37.5 \\
\hline S. Calcium(<8mg/dL) & 10 & 31.25 \\
\hline Table 5: Showing Laboratory Investigations \\
\hline
\end{tabular}

S-Serum, AST-Aspartate aminotransferase, UNL-upper normal limit

In the present study, most (75\%) of the patient's serum amylase was above 3 times upper normal limit, alkaline phosphatase was above $300 \mathrm{IU} / \mathrm{L}$ in $25 \%$ of patients, AST was raised in $50 \%$ of them, elevated serum bilirubin level in $37.5 \%$ of random blood sugar more than $150 \mathrm{mg} / \mathrm{dL}$ was present in $37.5 \%$ of the cases.

Ultrasonography of abdomen was done for all the 32 patients. It diagnosed acute gallstone pancreatitis in $24(75 \%)$ patients and did not diagnose in $8(25 \%)$ patients.

CT scan was done in all 32 patients and it could diagnose all the patients with acute gallstone pancreatitis. Mean CT severity index was 4.6. Choledochal cyst was seen in 2 patients and abnormal biliary and pancreatic duct junction was noted in 5 patients. Pancreatic necrosis $(<30 \%)$ was noted in 2 patients.

Average hospital stay in our study was 8 days (Range: 3-15 days). Three patients developed left sided pleural effusion and two developed right sided pleural effusion. Three of them underwent therapeutic pleural tapping and two were managed conservatively.

\section{FOLLOW-UP}

Eight patients underwent open cholecystectomy after an interval of 6-8 weeks. There was recurrence of acute gallstone pancreatitis in six patients (Recurrence rate: 18.75\%). Pseudocyst of pancreas developed in four patients (12.5\%) after 3-4 weeks of acute attack. All resolved without intervention 6-12 weeks after the discharge from hospital. 


\section{DISCUSSION}

Thirty two cases of acute gallstone pancreatitis were studied out of eighty cases of acute pancreatitis and constituted $40 \%$ of cases. The incidence of acute gallstone pancreatitis in studies of Ranson JHC et al. ${ }^{10}$ and Thomson SR et al.11 were $27 \%$ and $41 \%$ respectively. Finding of present study is similar to that of Thomson et al. ${ }^{11}$ Gallstones are the predominant causes of acute pancreatitis in North India as shown in the Table no. 6. However, in a recent South Indian study. ${ }^{12}$ gallstone accounted only for $13 \%$ of acute pancreatitis cases.
The highest age incidence was noticed in age group of 4160 years. The median age in the present study was 48 years, whereas in studies of Liu CL et al. ${ }^{13}$ and Armstrong et al. ${ }^{14}$ it was 69 and 54 years respectively.

Females were predominant in the present study (68.75\%), which was in contrast to the studies of Liu CL et al.13 (51.08\%) and Armstrong et al.14 (53\%). But, it is well known that acute gallstone pancreatitis is more common in females than in males. ${ }^{15-18}$ Only a few studies have standardised the incidence rate of age and sex.19-24

\begin{tabular}{|c|c|c|c|c|c|c|c|}
\hline & 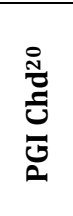 & 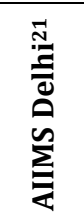 & 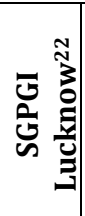 & 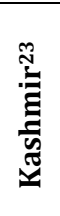 & 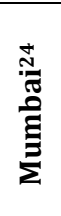 & 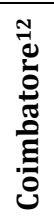 & 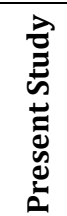 \\
\hline Gallstones (\%) & 35 & 44.6 & 45 & 48 & 14 & 13 & 40 \\
\hline Alcohol (\%) & 45 & 17.7 & 26 & 2.4 & 26 & 13 & 50 \\
\hline Ascariasis (\%) & & & & 22 & & & 1.25 \\
\hline Idiopathic (\%) & 16.8 & 25 & 19 & 21 & 48 & 40 & 7.5 \\
\hline Others (\%) & 3.2 & 12.7 & 10 & 6.6 & 12 & 34 & 1.25 \\
\hline
\end{tabular}

In the present study, acute pancreatitis occurred in $5.82 \%$ of patients with gallstone disease. This finding was in the range of the study of Pellegrini CA. ${ }^{1}$ In his study, acute pancreatitis occurred in $4-8 \%$ of the patients with gallstone disease.

Highest number of acute gallstone pancreatitis was seen in Meitei ethnic group (62.5\%), and Meitei Pangal (Muslim) had $18.75 \%$. Nepali, Naga and Kuki had $6.25 \%$ each. As ethnic/racial differences in the incidence rate of the acute pancreatitis have been suggested. ${ }^{25}$ we also propose that the difference of incidence in the various ethnic groups of Manipur could be because of differences in the food habit, anthropometric structure and genetic susceptibility. But, it has to be confirmed by further studies. $\mathrm{Ma} \mathrm{MH}$ et al. ${ }^{26}$ also observed that Hispanic children had $2.85(\mathrm{P}=0.01)$ and 5.59 $(\mathrm{P}=0.003)$ times higher probability for biliary pancreatitis than white and black children respectively.

All the patients in the present study presented with pain in epigastrium. Papavramidis TS et al. ${ }^{27}$ had similar observation, but Mohammad R et al. ${ }^{28}$ found epigastric pain in only $64.7 \%$ of their patients.

In the present study jaundice was present in $31.25 \%$, whereas in the studies of Mohammad R et al. ${ }^{18}$ and Liu CL et al. ${ }^{13}$ jaundice was present in $17.65 \%$ and $12 \%$ respectively.

In the present study, abdominal distension was present in $6.25 \%$ and fever was present in $18.75 \%$ while in the study of Liu CL et al. ${ }^{13}$ fever was present in $22 \%$.

In the present study, epigastric tenderness was present in all the patients (100\%), absent bowel sound was found in 12 patients (37.5\%) and hypotension was seen in 6 patients $(18.75 \%)$. But, Papavramidis et al. ${ }^{27}$ found no bowel sound in $73.5 \%$ of the patients.

In the present study, most (75\%) of the patient's serum amylase was above 3 times upper normal limit. In the study of Papavramidis et al.27 abnormal serum amylase was found in $95.37 \%$ of acute gallstone pancreatitis. In the study of Mohammad Ret al. 28 abnormal serum amylase was found in $72.6 \%$, which was similar to the present study.
In the present study, alkaline phosphatase was above 300 IU/L in 25\% of patients which was different from the finding of Mohammad R et al. ${ }^{28}$ They found abnormal alkaline phosphatase in $72.6 \%$ of the patients. Aspartate aminotransferase was abnormal in $50 \%$ of patients in the present study, but in the studies of Papavramidis et al. ${ }^{27}$ and Mohammad R et al. ${ }^{28}$ abnormality was $25 \%$ and $86.3 \%$ respectively.

In the present study, elevated serum bilirubin was found in $37.5 \%$ of the patients but in the study of Mohammad R et al. ${ }^{28}$ elevated serum bilirubin level was found in $56.9 \%$ of the patients.

Gungor B et al.29 suggested that increased alkaline phosphatase, total bilirubin, direct bilirubin, amylase and lipase levels might be used in prediction of biliary pancreatitis.

USG of abdomen was done to all the 32 patients. It diagnosed acute gallstone pancreatitis in about 24(75\%) patients. It was almost similar to the study of Papavramidiset al. ${ }^{26}$ where 78 out of $108(72.22 \%)$ were diagnosed by ultrasound. Failure to diagnose acute pancreatitis could be due to excess gas in the intestine and thick fat in the abdomen, which limit the penetration of acoustic wave. ${ }^{30}$

CT scan was done in 20 patients and diagnosis of acute gallstone pancreatitis could be done in all patients (100\%). Papavramidis et al. ${ }^{26}$ could diagnose acute gallstone pancreatitis in $92.59 \%$ of patients.

The average hospital stay in the present study was 8 days, but it was 10.53 days in the study of Papavramidis et al. ${ }^{26}$

On followup, there was recurrence of the disease in 6 patients (18.75\%) and 2 patients developed pseudocyst of pancreas. All of them were managed conservatively. According to Balthazar EJ et al. ${ }^{31}$ pseudocyst of pancreas could occur in $10-20 \%$ of patients following acute pancreatitis.

According to Pellegrini. ${ }^{1}$ acute pancreatitis recurred in $50 \%$ of the patient within 1-6 months whenever patient was not submitted to cholecystectomy and cleansing of common bile duct. 
After a systemic review, Van Baal MC et al. ${ }^{32}$ concluded that after mild biliary pancreatitis, the risk of readmission for recurrent biliary events is high while waiting for interval cholecystectomy and cholecystectomy during index admission for mild biliary pancreatitis appeared safe, but selection bias could not be excluded.

\section{CONCLUSION}

Genetic basis of occurrence of biliary pancreatitis among the various ethnic groups of Manipur needs to be addressed. Serum amylase and ultrasonography were useful initial investigative modality in diagnosing acute gallstone pancreatitis.

The acceptance of index cholecystectomy in our local population is very low and the awareness of treatment modalities has to be increased.

\section{REFERENCES}

1. Pellegrini CA. Surgery for gallstone pancreatitis. Am J Surg 1993;165(4):515-8.

2. Taylor TV, Rimmer S. Pancreatic duct reflux in patients with gallstone pancreatitis? Lancet 1980;1:848-51.

3. Thomson SR, Hendry WS, McFarlane GA, et al. Epidemiology and outcome of acute pancreatitis. Br J Surg 1987;74(5):398-401.

4. Opie EL. The etiology of acute hemorrhagic pancreatitis. Bull Johns Hopkins Hosp 1901;12:18.

5. Eland IA, Sturkenboom MJ, Wilson JH, et al. Incidence and mortality of acute pancreatitis between 1985 and 1995 . Scand J Gastroenterol 2000;35:1110-6.

6. Sekimoto M, Takada T, Kawarada Y, Hiarata K, Mayumi T, Yoshida M, et al. JPN guidelines for the management of acute pancreatitis: epidemiology, etiology, natural history and outcome predictors in acute pancreatitis. J Hepatobiliary Pancreat Surg 2006;13:10-24.

7. Wen-kui Yu, Wei-Qin Li, Ning Li, et al. Mononuclear histocompatibility leukocyte antigen-DR expression in the early phase of acute pancreatitis. Pancreatology 2004;4:233-43.

8. Lindkvist B, Appelrose S, Manjer J, et al. Trends in incidence of acute pancreatitis in a Swedish population: is there really an increase? Clin Gastroenterol Hepatol 2004;2(9):831-7.

9. Floyd A, Pederson L, Nielsen GL, et al. Secular trends in the incidence and 30-day case fatality of acute pancreatitis in North Jutland County: a register based study from 1981-2000. Scand J Gastroenterol 2002;37(12):1461-5.

10. Ranson JH, Rifkind KM, Roses DF, Fink SD, Eng K, Spencer FC: Prognostic signs and the role of operative management in acute pancreatitis. SurgGvnecolObstet 1974;139:69-81.

11. Thomson SR, Hendry WS, McFarlane GA, et al. Epidemology and outcome of acute pancreatitis. Br J Surg 1987;74(5):398-401.

12. Prasad M, Shetty A, Nathan VM, et al. Prevalence of acute pancreatitis and its different etiologies in South Indian population. Indian J Gastroenterol 2004;23 (suppl 2): A72.

13. Liu CL, Fan ST, Lo CM, Tso WK, Wong Y, Poon RTP, et al. Clinico-biochemical prediction of biliary cause of acute pancreatitis in the era of endoscopic ultrasonography. Aliment Pharmacol Ther 2005;22:423-31.
14. Armstrong CP, Taylor TV, Jeacock J, et al. The biliary tract in patients with acute gallstone pancreatitis. Br J Surg 1985;72:551-55.

15. Ranson JH. Etiology and prognostic factors in human acute pancreatitis: a review. Am J Gastroenterol 1982;79(9):633-8.

16. Bell AM, O'Rouke MG. Gallstone pancreatitis. Med J Aust 1986;144(11):572-4

17. Pezzilli R, Billi P, Morselli-Labate AM. Severity of acute pancreatitis: relationship with etiology, sex and age. Hepatogastroenterology 1998;45(23):1859-64.

18. Singal AK, Elamin AH, Ayoola AE. Profile of acute pancreatitis in Jizan, Saudi Arabia. Saudi Med J 2003;24(1):72-5.

19. Eland IA, Sturkenboom MJ, Wilson JH, et al. Incidence and mortality of acute pancreatitis between 1985 and 1995 Scand J Gastroenterol 2000;35:1110-6.

20. Wig JD, Bharathy KG, Kochhar R, Yadav TD, Kudari AK, Doley RP, et al. Correlates of organ failure in severe acute pancreatitis. JOP 2009;10(3):271-5.

21. Garg PK, Madan K, Pande GK, Khanna S, Sathyanarayan G, Bohidar NP, et al. Association of extent and infection of pancreatic necrosis with organ failure and death in acute necrotizing pancreatitis. Clin Gastroenterol Hepatol 2005;3(2):159-66.

22. Bhat G, Singh D, Choudhuri G. Profile of acute pancreatitis at tertiary center. Indian J Gastroenterol 2006;25(suppl 2):A113.

23. Zargar SA, Gupta A, Javid G. Clinical profiles of Acute Pancreatitis in 648 cases: a hospital based study. Indian J Gastroenterol 2007;26(suppl 2):A105.

24. Patil SS, Bhatt J, Abraham P, et al. A clinical spectrum of patients with acute pancreatitis in a tertiary hospital in India. Indian J Gastroenterol 2007;26(suppl 2):A106.

25. Frey CF, Zhou H, Harvey DJ, et al. The incidence and case fatality rate of acute biliary, alcoholic and idiopathic pancreatitis in California, 1994-2001. Pancreas 2006;33:336-44.

26. Ma MH, Bai HX, Park AJ, Latif SU, Mistry PK, PashankarD. Risk factors associated with biliary pancreatitis in children. J Pediatr Gastroenterol Nutr. 2012;54(5):651-6.

27. Papavramidis TS, Zandes N, Hatzimisios K, Koutsimani T, Kehagia F, Agorastou P, et al. Acute gallstone pancreatitis: a constant challenge for the surgeon. Indian J Surg 2008;70:224-6.

28. Mohammad R, Fakhar H, Bashir A. Incidence of SIRS in acute biliary pancreatitis. APMC 2009;3(1):59-62.

29. Gungor B, Caglayan K, Polat C, Seren D, Erzurumlu K, Malazgirt Z. The predictivity of serum biochemical markers in acute biliary pancreatitis. ISRN Gastroenterol 2011;2011:279607. Epub 2010 Dec 14.

30. Bennett GL, Hann LE. Pancreatic ultrasonography. Surg Clin North Am 2001;81(2):259-81.

31. Balthazar EJ, Freeny PC, van Sonnenberg E. Imaging and intervention in acute pancreatitis. Radiology 1994;193(2):297-306.

32. Van Baal MC, Besselink MG, Bakker OJ, van Santvoort HC, Schaapherder AF, Nieuwenhuijs VB, et al. Timing of cholecystectomy after mild biliary pancreatitis: a systematic review. Ann Surg 2012;255(5):860-6. 